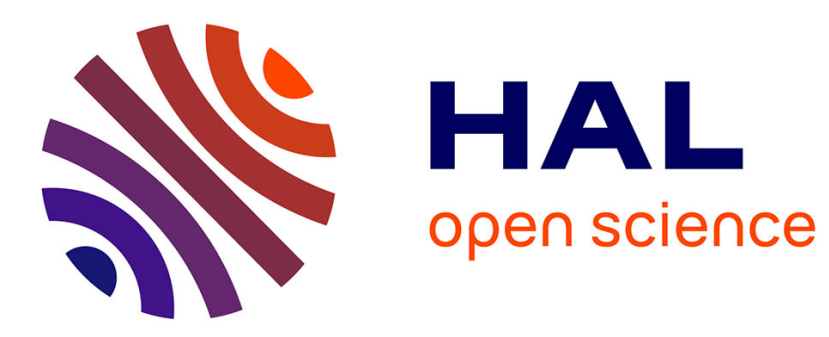

\title{
A cryogenic sample changer
}

The Sample Environment Group

\section{To cite this version:}

The Sample Environment Group. A cryogenic sample changer. Revue de Physique Appliquée, 1984, 19 (9), pp.801-802. 10.1051/rphysap:01984001909080100 . jpa-00245265

\section{HAL Id: jpa-00245265 https://hal.science/jpa-00245265}

Submitted on 1 Jan 1984

HAL is a multi-disciplinary open access archive for the deposit and dissemination of scientific research documents, whether they are published or not. The documents may come from teaching and research institutions in France or abroad, or from public or private research centers.
L'archive ouverte pluridisciplinaire HAL, est destinée au dépôt et à la diffusion de documents scientifiques de niveau recherche, publiés ou non, émanant des établissements d'enseignement et de recherche français ou étrangers, des laboratoires publics ou privés. 


\title{
A cryogenic sample changer
}

\author{
The Sample Environment Group \\ Neutron Division, Rutherford Appleton Laboratory, Chilton, Didcot, Oxon, U.K.
}

\begin{abstract}
Résumé. - Un changeur d'échantillons a été mis au point pour des températures comprises entre $30 \mathrm{~K}$ et $300 \mathrm{~K}$, en utilisant un cryostat à circuit fermé d'hélium. Le refroidissement est obtenu en améliorant la conductivité thermique entre les porte-échantillons en aluminium et les barres de refroidissement en cuivre. On présente l'ensemble de l'appareil et quelques résultats préliminaires.
\end{abstract}

\begin{abstract}
A sample changer has been designed for cooling samples to ca. $30 \mathrm{~K}$ from ambient temperatures, using a closed cycle helium refrigerator to obtain the cryogenic temperatures. Cooling is achieved by producing good conductive contact between the aluminium sample holders and the copper cooling bars. The apparatus, and some preliminary results will be presented.
\end{abstract}

\section{Introduction.}

The importance of cryogenic temperatures in solid state materials research, is well established and is expected to continue on the SNS. Some SNS neutron spectrometers will complete experiments very rapidly, hence any time spent changing samples becomes wasteful. This will be especially true where samples cannot be cooled by an exchange gas. Since radiant heat transfer is very inefficient at these temperatures the only viable alternative heat transfer process is conduction, by metal to metal contact.

A cryogenic sample changer has been developed which is suitable over the temperature range 30 to $300 \mathrm{~K}$. The sample holders changing mechanism and heat transfer processes are presented below.

\section{The sample holders.}

The sample holder consists of two principle parts; the aluminium frame, and the top and bottom copper contact strips. The aluminium is used for its neutron properties, and the copper strips are out of the beam area. The thermal diffusivity of copper and aluminium is similar over the cryogenic temperature range. Therefore, provided that good thermal contact is established between them, the two metals will behave as a sample of a single metal. This is achieved in our sample holder by friction welds (although high tensile steel bolts can be used).

\section{The sample changer.}

The prototype sample changer for 10 samples uses a closed cycle refrigerator to provide cooling power.
Above the vacuum tight lid are a stepping motor, which rotates a carousel supporting the samples; and pneumatic cylinders which displace two samples down. The first sample is pushed down onto a massive supporting cold arm which is just above the level of the beam, and the second sample is pushed down into the beam area, also contacting a cold arm. The first cold arm will take the sample down to $c a .90 \mathrm{~K}$ in about $15 \mathrm{~min}$ from room temperatures. The second cold arm although not yet tested, is designed for operations $c a .30 \mathrm{~K}$. Sample moving speeds are not a limiting factor. Thus the stepping motor can be driven one step at a time by the controlling microprocessor. The most important characteristic of a stepping motor under these conditions is its pull-out torque. A simple gear train provides a mechanical advantage of $4: 1$. and backlash is avoided by allow ing only clockwise rotation of the carousel. The pneumatic cylinder is double acting and by controlling the air flow a smooth sample displacement can be achieved. Since the axis of the push rod is concentric with the axis of rotation of the sample in the scattering plane it is possible to obtain any sample angle by rotating the top plate.

The positions of the samples are determined by the use of opto switches and reed switches. The opto switch is closed when a sample is in the retracted position. The closure of this switch is tested before the pneumatic cylinder is opened or the carousel is rotated. The sample position is interrogated by the controlling microprocessor for consistency, any inconsistency causes the sample changer to stop with all the samples retracted. 
The positions of the samples were measured for accuracy of location. in the Cartesian coordinate frame. The $Z$ axis is vertical and the $Y$ axis aligns along a radius of the carousel. The individual sample positions were reproduced to an accuracy better than the resolution of our gauge $\mp 0.0125 \mathrm{~mm}$, in the $X-Y$ plane. In the $Z$ direction the sample relocation was better than $0.5 \mathrm{~mm}$. It is usual to relax the vertical divergence of neutron beams and so the discrepancies between errors in the $X-Y$ plane to those of $Z$ is acceptable.

Assuming Gaussian statistics the standard error on the replacement of one sample by any other is, $\mp 0.07 \mathrm{~mm}$. This error can be attributed to the systematic errors inherent in any mechanical construction.

\section{The heat transfer process.}

The most efficient heat transfer process is by electron flow across the interface to the cold bars from the sample (another, less efficient process, involves the flow of phonons). Because of the mechanical strength and insulating properties of aluminium oxide, contact conductances (watts per meter squared per degree) of aluminium are low. Copper can give reasonable conductances but the best is obtained with gold. Unfortunately gold plated aluminium samples have very poor contact conductances because the gold does not adhere directly to the aluminium. This explains the need for copper conducting strips on the sample frame. The copper on the sample frame and on the cold arm are both gold plated.

Further improvements in the heat flow between metals can be obtained by increasing, the surface areas in contact and the pressures involved. However, in the context of cryogenic engineering very high pressures are not anticipated. It is more profitable to ensure flat contact between the sample and the cold arm than to increase the contact pressure (NB flatness not smoothness!). 